\title{
Analisis Sistem Informasi Manajemen dalam Penggunaan Aplikasi Blibli
}

\author{
Rizal Akda PAMUNGKAS \\ Fakultas Ekonomi, STIE STEMBI Bandung Business School, Jalan Buah Batu No.26 Burangrang Kec. Lengkong \\ Kota Bandung, Jawa Barat, Indonesia \\ rizalakdapamungkas20@student.stembi.ac.id
}

Suci RAHMAYATI
Fakultas Ekonomi, STIE STEMBI Bandung Business School, Jalan Buah Batu No.26 Burangrang Kec. Lengkong
Kota Bandung, Jawa Barat, Indonesia
sucirahmayati20@student.stembi.ac.id

Ricky FIRMANSYAH

Program Studi IImu Komunikasi, Universitas Ars, Jalan Sekolah Internasional No. 1-2 Bandung, Jawa Barat, Indonesia

ricky@ars.ac.id

\section{Article's history:}

Received 9 January 2021; Received in revised form 11 February 2021; Accepted 15 February, 2021; Published 28 February 2021. All rights reserved to the Lembaga Otonom Lembaga Informasi dan Riset Indonesia (KITA INFO dan RISET).

\section{Suggested citation:}

Pamungkas, A.R., Rahmayati, S, Firmansyah, R. 2021. Analisis Sistem Informasi Manajemen dalam Penggunaan Aplikasi Blibli. JEMSI (Jurnal Ekonomi, Manajemen, dan Akuntansi), Volume 7 (1): 33-41. DOI: https://doi.org/10.35870/jemsi.v7i1.525.

\section{ABSTRAK:}

Tujuan dari penelitian ini adalah untuk mendapat pemahaman mendalam di lapangan dengan lebih spesifik dan transparan guna mengumpulkan informasi secara aktual dan rinci serta menggambarkan sistem informasi yang ada dalam aplikasi blibli.com juga mengetahui keefektifan penggunaan aplikasi blibli.com sebagai bentuk dari sistem informasi. Metode yang digunakan dalam penelitian ini adalah metode deskriptif kuantitatif dengan pendekatan metodologis. Penelitian ini dilakukan dengan menganalisis dan mengidentifikasi masalah, kegunaan, dan sistem informasi yang berlaku, melihat dan mengetahui keefektifan sistem informasi yang tersedia dalam aplikasi blibli.com dengan membaca komentar-komentar masyarakat mengenai kelebihan atau kekurangan dari sistem informasi yang tersedia. Hasil dari penelitian ini adalah jika merujuk pada jumlah pengguna terbanyak blbl dinilai belum cukup efektif karena verada diurutan terakhir jika dibandingkan dengan ecommerce lainnya. Kemuadian dari 20 pengguna aplikasi blibli terdapat 40\% pengguna menyatakan aplikasi blibli telah memberikan kenyamanan dan kepuasan belanja melalui 24/7 layanan customer care yang artinya blibli sudah cukup efektif, namun jika dilihat dari kepastian 15 hari pengembalian libli dinilai tidak efektif karena sebesar $65 \%$ pengguna menyatakan tidak dapat melakukan retur atau pengembalian barang. Merujuk pda visi yang terakir aplikasi blbli sudah dinilai efektif karena telah menyediakan metode pembayaran yang lengkap untuk melakukan traksaksi dalam aplkasi blibli tersebut.

Kata Kunci: Blibli.com; E-commerce; Efektivitas; Sistem Informasi.

JEL Classification: L86; D83; L81.

\section{PENDAHULUAN}

Berkembangnya teknologi dalam dunia bisnis membuat sistem informasi manajemen sangat dibutuhkan untuk membantu kegiatan bisnis agar tetap bisa berjalan dengan baik. Nyaris di setiap bidang pasti memerlukan sebuah sistem yang mampu mengatur dan mengurus sebuah informasi dengan baik dan benar. Istilah sistem merupakan asal kata dari bahasa Latin (systēma) dan juga berasal dari bahasa Yunani (sustēma). Secara bahasa sistem adalah suatu kesatuan yang terdiri atas komponen atau elemen yang dihubungkan bersama untuk mempermudah aliran informasi, materi, atau energi untuk mencapai suatu tujuan (Sendari, 2021). Secara etimologi, dilihat dari bahasa Perancis informasi disebut sebagai informacion yang memiliki arti konsep, ide, atau 
garis besar. Informasi sendiri merupakan kata benda yang memiliki arti aktivitas dalam pengetahuan yang dikomunikasikan. Informasi merupakan data-data atau fakta yang dikelola menjadi sesuatu yang bermanfaat bagi penerimanya. Biasanya, informasi akan diolah terlebih dahulu supaya penerima mudah memahami informasi yang akan diterimanya. Sederhananya, informasi sudah diolah menjadi bentuk yang lebih berharga (Nugraha, 2021). Sedangkan Sistem informasi manajemen menurut (Adani, 2020) adalah sekelompok atau sekumpulan proses dimana data dapat diolah, dianalisis, dan ditampilkan supaya data tersebut menjadi berguna untuk kebutuhan pengambilan suatu keputusan. Sistem ini merupakan alat yang sangat berguna untuk menunjang dan mengendalikan operasi perusahaan (Adani, 2020). Penggunaan dari sistema informasi sendiri bertujuan untuk mengolah berbagai informasi yang dikelola oleh setiap perusahaan atau organisasi, sehingga sumber daya atau resources yang dibutuhkan tidak terlalu besar dan dapat mempersingkat waktu penanganan proses. Selain itu, data yang dikelola juga dapat digunakan kapan saja dan dimana saja, serta mampu mempersingkat birokrasi yang ada (Adani, Pengertian Sistem Informasi dan Contoh Penerapan pada Dunia Industri, 2021) . Secara ilmiah, istilah ini biasanya dimasukkan dalam golongan metode manajemen informasi yang saling berkaitan dan dapat menjadi salah satu tolak ukur terhadap pengambilan keputusan manusia, contohnya seperti sistem pendukung keputusan, sistem pakar, serta sistem informasi eksekutif. Adapun perbedaan sistem informasi manajemen dengan sistem informasi biasa lainnya adalah dikarenakan sistem ini secara otomatis dapat menyediakan analisis terhadap sistem informasi lain. (Rahma, 2021).

Salah satu bentuk dari sistem informasi adalah aplikasi marketplace, yaitu Blibli.com Blibli.com adalah salah satu e-commerce di Indonesia dengan konsep belanja yang dilakukan secara online. Dengan konsep tersebut blibli berharap warga Indonesia yang biasanya belanja di mall dapat menemukan barang yang mereka butuhkan dengan cepat, mudah dan menyenangkan tanpa harus pergi ke toko atau mall karena dimanapun dan kapanpun blibli dapat diakses dengan mudah. Blibli ialah produk pertama PT Global Digital 0 yang mana merupakan salah satu anak perusahaan Djarum di bidang digital sudah berdiri sejak tahun 2010. Blibli berkolaborasi dengan teknologi provider internasional, mitra logistik, banking partner serta merchant partner yang memiliki standar tertentu guna menciptakan sistem back-end yang sanggup memenuhi keperluan para pengguna blibli. Saat ini Djarum Group melalui Global Digital Prima Ventures (GDP) misalnya, membentuk inkubator bernama Merah Puth Inc, sebuah inkubator startup lokal berbasis komunitas dan memberikan bantuan modal bagi startup lokal yang inovatif. Kantor pusat Blibli bermarkas di Jakarta Barat dengan biaya infrastruktur seperti server dan jaringan hampir mencapai Rp 100 miliar (Abdirrosyid \& Misbahuddin, 2017).

Blibli.com saat ini memang dibutuhkan dan memberikan dampak positif maupun negatif. Terlebih saat ini dunia tengah dilanda oleh pandemi covid-19 dimana dengan adanya aplikasi blibli ini semua orang masih tetap bisa memenuhi kebutuhan belanjanya tanpa harus keluar dan tetap menaati protokol kesehatan. Selain itu, dengan adanya aplikasi blibli.com sebagai bentuk dari sistem informasi merupakan tuntutan juga yang harus dipenuhi karena saat ini persaingan di dunia usaha semakin ketat dan inovasi-inovasi baru pada bidang usaha sangat dibutuhkan dalam dunia bisnis untuk mencapai tujuan bisnis perusahaan yang bekerja secara efektif dan efisien. Aplikasi blibli.com dapat dikatakan sebagai salah satu bentuk dari sistem informasi karena aplikasi tersebut mampu memberikan dan menyediakan informasi kepada publik. Contohnya saja, ketika anda akan berbelanja menggunakan marketplace tersebut Anda dapat mengakses informasi mengenai barang yang akan anda beli seperti jumlah, harga, lokasi penempatan, kualitas, stok dan lain sebagainya. Adanya berbagai jenis marketplace juga menunjukkan perkembangan teknologi dan sistem informasi yang terus berkembang dan membuat inovasiinovasi baru dalam dunia bisnis.

\section{TINJAUAN KEPUSTAKAAN}

Aplikasi blibli.com mempermudah proses untuk menjual produknya karena transaksi dilakukan secara online, memberikan kemudahan dalam proses jual beli dan mendapatkan informasi tentang produk yang bersangkutan serta memudahkan komunikasi antara konsumen dan pihak blibli (Aryatama). Penelitian lain tentang aplikasi blibli juga dilakukan oleh (Kusniadi, p. 2) yang mengatakan bahwa kehadiran E-commerce sebagai media transaksi yang baru, cepat dan mudah ini tentunya menguntungkan banyak pihak baik pihak konsumen maupun pihak produsen dan penjual atau retailer dengan menggunakan internet proses jual beli dapat dilakukan dengan menghemat biaya dan waktu.

Penelitian selanjutnya dilakukan oleh (Lathiif, 2019) yang mengatakan aplikasi blibli.com memiliki tujuan untuk memberikan wadah kepada masyarakat untuk melakukan proses pembelian barang dan mendapat informasi 
memberikan ulasan dan memberikan rekomendasi rekomendasi mengenai suatu produk sehingga masyarakat dapat mengambil keputusan dalam berbelanja secara online. Selain penilaian penilaian positif aplikasi blibli.com juga memiliki penilaian yang negatif seperti yang dikatakan oleh (Lathiif, Pengaruh Kepercayaan, Kemudahan, Dan Kualitas Informasi terhadap Keputusan Pembelian, 2019) menyatakan bahwa adanya kesalahan pengiriman yang dilakukan pihak blibli.com karena menggabungkan dua pesanan dalam satu pengiriman melalui dua username terpisah harga hanya karena nama dan alamat penerima sama dan hal ini tidak diinformasikan kepada pelanggan sebelum barang diantar. Alhasil pihak logistik hanya menyerahkan 1 buah kardus dan dan ketika memeriksa isi kardus ternyata hanya terisi satu barang saja. Penelitian ini dilakukan untuk mengetahui informasi apa yang ada dan yang dapat kita peroleh dalam aplikasi blibli.com serta mengetahui keefektifan penggunaan aplikasi blibli.com sebagai salah satu bentuk dari sistem informasi.

\section{METODE PENELITIAN}

Metodologi pada dasarnya merupakan kegiatan, peraturan, prosedur yang dipakai dalam penelitian serta sebuah analisis teoritis tentang sebuah metode atau cara. Menurut (Saat \& Mania, 2020) metode merupakan seperangkat langkah dari apa yang harus dikerjakan secara tersusun dan sistematis. metodologis berfokus terhadap indikator dan faktor yang diteliti secara mendetail dan berguna untuk memberikan arah dan menjelaskan apa yang diteliti. Metode deskriptif kuantitatif berfokus pada filsafat post positivisme digunakan untuk meneliti pada kondisi objek yang alamiah (sebagai lawannya adalah eksperimen) dimana peneliti adalah sebagai instrumen kunci teknik pengumpulan data dilakukan secara triangulasi (gabungan), analisis data bersifat kuantitatif, dan hasil penelitian kuantitatif lebih menekankan makna daripada generalisasi (Fitrah \& Luthfiyah, 2017).

Tujuan dari penelitian deskriptif ini ditujukan untuk mendapat pemahaman mendalam di lapangan dengan lebih spesifik dan transparan guna mengumpulkan informasi secara aktual dan rinci yang serta menggambarkan sistem informasi yang ada dalam aplikasi blibli.com. Menganalisis dan mengidentifikasi masalah, kegunaan, dan sistem informasi yang berlaku. Melihat dan mengetahui keefektifan sistem informasi yang tersedia dalam aplikasi blibli.com dengan membaca komentar-komentar masyarakat mengenai kelebihan atau kekurangan dari sistem informasi yang tersedia. Sedangkan proses pengambilan data dalam penelitian ini dilakukan dengan melakukan percobaan dalam menggunakan aplikasi yang menjadi sumber utama (blibli.com) menghasilkan data. Sumber data lainnya diambil dari berbagai media yang di muat mengenai data-data tentang aplikasi blibli.com, berupa laporan keuangan, profil perusahaan, artikel sebagai teori, dan lain sebagainya.

Metode atau teknik penelitian yang digunakan dalam penelitian ini adalah metode deskriptif kuantitatif. Metode penelitian kuantitatif ini dapat diartikan sebagai penelitian yang berlandaskan pada filsafat positivisme, dapat juga dimanfaatkan untuk meneliti atau mengkaji populasi atau sampel tertentu. Gaya pengambilan sampel pada umumnya dilakukan secara acak, pengumpulan data menggunakan instrumen penelitian. seperti halnya yang di dikatakan (Noer \& Dayana, 2021) positivisme secara terminologi berarti suatu paham yang dalam "pencapaian kebenaran"-nya bersumber dan berpangkal pada kejadian yang benar-benar terjadi..

\section{HASIL PENELITIAN DAN PEMBAHASAN}

Masa teknologi saat ini sangat membutuhkan jangkauan yang lebih luas lagi, terutama untuk mengedepankan kebutuhan sehari-hari. Hal ini bertujuan guna memperoleh fleksibilitas dan efektivitas dalam teknologi. Karena terdapat banyaknya bukti fisik bahwa banyaknya masyarakat yang menggunakan teknologi untuk dapat mempermudah segala urusan dalam kebutuhannya. Baik itu dalam hal berkomunikasi, belanja secara online, pemesanan transportasi online, dan lain sebagainya. Di abad ke $\square 21$ ini, penerapan sistem informasi tidak hanya diimplementasikan pada bidang Teknologi Informasi dan Komunikasi (TIK) saja, namun kebutuhan proses bisnis lain juga sangat membutuhkan kontrol dari SI. Sehingga, sistem informasi dapat terbentuk sebagai model khusus dari proses kerja. Penerapan dari sistem informasi sendiri mengacu pada proses pengolahan data dari berbagai informasi yang dikelola oleh setiap perusahaan atau organisasi, sehingga sumber daya atau resources yang diperlukan tidak terlalu besar dan dapat mempercepat waktu penyelesaian proses kerja. Selain itu, data yang dikelola juga dapat digunakan kapan saja dan dimana saja, serta mampu mempersingkat birokrasi yang ada (Adani, Pengertian Sistem Informasi dan Contoh Penerapan pada Dunia Industri, 2021).

Penelitian ini dilakukan dengan cara pengumpulan data dalam aplikasi blibli.com yang kemudian dianalisis dan disimpulkan menjadi sebuah fakta lapangan mengenai informasi aplikasi tersebut. Dan berikut 
adalah pengumpulan data hasil penelitian yang kami lakukan mengenai informasi yang ada dan yang dapat kita peroleh dalam aplikasi blibli.com.

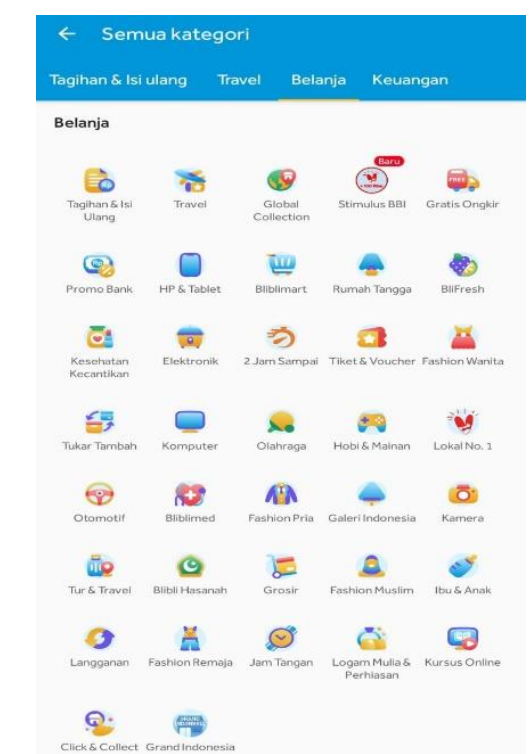

Gambar 1. Fitur-Fitur Aplikasi Blibli.com Sumber: https://www.blibli.com/home/favourites

Aplikasi blibli.com memiliki 4 (empat) fitur diantaranya adalah fitur tagihan dan isi ulang, fitur travel, fitur belanja dan fitur keuangan. Dalam penelitian ini kami memfokuskan hanya membahas 1 (satu) fitur, yaitu fitur belanja. Dimana fitur belanja ini salah satunya memiliki layanan berupa bliblimart, yaitu fitur yang menyediakan kebutuhan rumah tangga seperti makanan, minuman, kebutuhan ibu dan anak, perawatan rumah tangga, perawatan kulit tubuh dan produk grosiran. Keuntungan yang bisa didapatkan dengan berbelanja dibliblimart adalah same day delivery, gratis ongkir, dan harga bersaing. Fitur bliblimart ini sangat dibutuhkan di tengah wabah covid-19 karena memudahkan konsumen untuk membeli produk yang diinginkan tanpa harus keluar rumah dan langsung berkunjung ke toko.

$$
\leftarrow \text { Deskripsiproduk }
$$

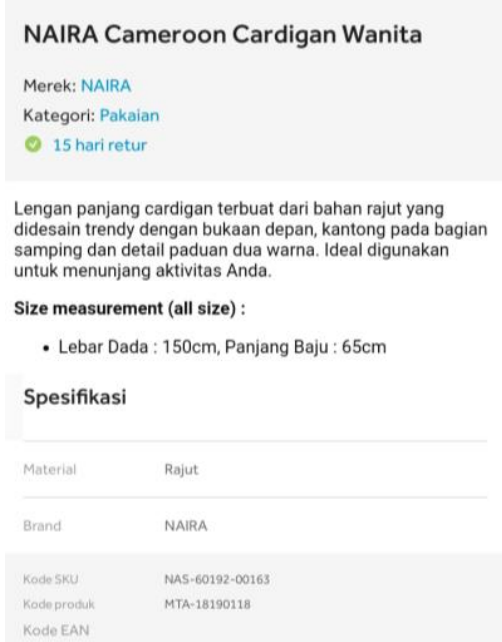

Gambar 2. Deskripsi Salah Satu Produk dalam Layanan Bliblimart Sumber: https://blibli.app.link/7TX1bo1cmlb

Gambar di atas merupakan informasi yang ada dan yang dapat kita peroleh dalam aplikasi blibli.com mengenai layanan bliblimart dalam fitur belanja. Dimana dalam gambar di atas berisi deskripsi dari salah satu produk. Deskripsi tersebut bisa memberikan kita informasi mengenai merek produk, kategori produk, deskripsi 
produk, size produk dan spesifikasi produk. Dengan adanya deskripsi produk memudahkan konsumen untuk mengetahui informasi mengenai produk yang diminati dan menentukan untuk membeli produk tersebut atau tidak.

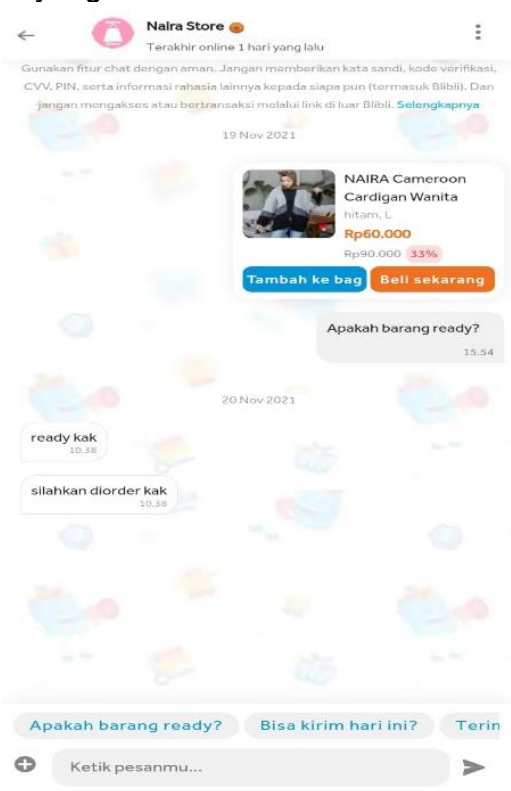

Gambar 3. Fitur Chat dalam Aplikasi Blibli.com

Sumber: https://www.blibli.com/member/seller-chat/AZO-60029?itemSku=AZO-60029-01697-00002

Selain menyediakan deskripsi produk layanan bliblimart juga menyediakan fitur chat untuk memudahkan komunikasi antara konsumen dan penjual. Dengan adanya fitur chat ini, konsumen bebas menanyakan apa saja mengenai produknya guna mendapatkan informasi lebih detail sebagai pertimbangan untuk melakukan proses jual beli atau tidak.

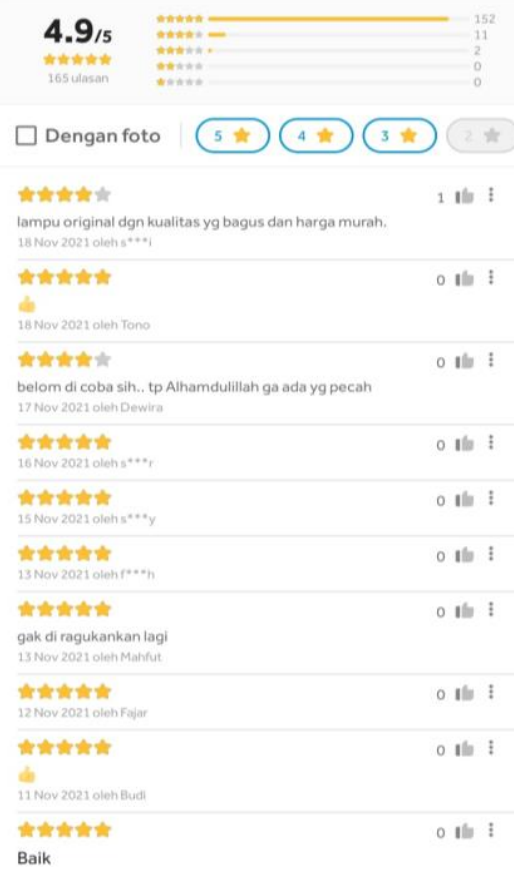

Gambar 4. Fitur Ulasan dalam Aplikasi Blibli.com https://www.blibli.com/p/hannochs-nex-lampu-led-set-5-watt-5-pcs-cahaya-putih/is--EMS-60033-00181-00001 
Terakhir, layanan bliblimart juga menyediakan fitur ulasan, fitur ulasan ini berisi penilaian pembeli mengenai suatu produk yang telah dibelinya apakah produk tersebut bagus atau tidak. Fitur ulasan ini sangat bermanfaat, baik bagi calon konsumen ataupun penjual. Bermanfaat bagi calon konsumen yaitu sebagai pertimbangan untuk produk yang akan dibelinya, seperti contoh pada gambar di atas ulasan-ulasan dari konsumen sebelumnya sangat bagus dan positif jadi dapat menjadi nilai tambah untuk calon konsumen yang akan membelinya. Sedanngkan bagi penjual sendiri bermanfaat karena ulasan tersebut dapat dijadikan kritik dan saran jika ada konsumen yang tidak puas atau produk yang kurang bagus.

Selain melakukan penelitian mengenai informasi yang ada dan yang dapat diperoleh dari aplikasi blibli, kami juga melakukan penelitian mengenai seberapa efektif aplikasi blibli sebagai salah satu e-commerce dengan merujuk pada visi dari aplikasi blibli itu sendiri. Efektivitas adalah suatu ukuran seberapa jauh target baik itu kuantitas, kualitas dan waktu telah tercapai sesuai dengan apa yang direncanakan. Semakin besar persentase target yang tercapai maka semakin besar keefektifannya dan sebaliknya semakin kecil persentase target yan tercapai maka semakin kecil keefektifannya (Prawiro, 2018). Data penelitian ini diperoleh dari aplikasi blibli, play store serta web yang menyediakan informasi yang bersangkutan, kemudian dianalisis dan disimpulkan menjadi sebuah fakta lapangan mengenai seberapa efektif aplikasi blibli. Dan berikut adalah pengumpulan data hasil penelitian yang kami lakukan keefektifan aplikasi blibli sebagai salah satu e-commerce. Dikutip dari web blibli , aplikasi blibli mempunyai visi sebagai e-commerce nomor satu yang memiliki jumlah pelanggan atau pengguna setia terbanyak di Indonesia, Blibli berkomitmen untuk dapat memberikan kenyamanan, keamanan serta kepuasan belanja via 24/7 jasa Customer Care, kejelasan 15 hari pengembalian produk serta pilihan atau alternatif pembayaran yang lengkap dan aman bagi pelanggan.

Dilihat dari visi yang pertama aplikasi blibli yaitu menjadi e-commerce nomor satu yang memiliki jumlah pelanggan terbanyak. Namun, berdasarkan penelitian yang kami lakukan blibli belum menjadi e-commerce dengan pelanggan terbanyak karena jika dibandingkan dengan marketplace populer lainnya seperti aplikasi shopee, tokopedia, Lazada dan bukalapak aplikasi blibli ini berada diurutan paling terakhir baik dilihat dari jumlah pengguna aplikasi ataupun jumlah kunjungan web. Berdasarkan informasi yang telah kami dapatkan berikut adalah data perbandingan mengenai jumlah pengguna aplikas $d$, jumlah kunjungan web dalam aplikasi e-commerce yang populer di Indonesia.

Tabel 1. Data Perbandingan Jumlah Pengguna Aplikasi E-commerce Terbanyak

\begin{tabular}{|l|l|l|}
\hline \multicolumn{1}{|c|}{ E-commerce } & \multicolumn{1}{c|}{ Jumlah Pengguna } & \multicolumn{1}{c|}{ Jumlah Kunjunga Web } \\
\hline Tokopedia & $\begin{array}{l}\text { Telah didownload lebih dari } \\
100.000 .000 \text { pengguna }\end{array}$ & 147.790 .000 \\
\hline Shopee & $\begin{array}{l}\text { Telah didownload lebih dari } \\
100.000 .000 \text { pengguna }\end{array}$ & 126.996 .700 \\
\hline Bukalpak & $\begin{array}{l}\text { Telah didownload lebih dari } \\
50.000 .000 \text { pengguna }\end{array}$ & 29.460 .000 \\
\hline Lazada & $\begin{array}{l}\text { Telah didownload lebih dari } \\
100.000 .000 \text { pengguna }\end{array}$ & 27.670 .000 \\
\hline Blibli & $\begin{array}{l}\text { Telah didownload lebih dari } \\
10.000 .000 \text { pengguna }\end{array}$ & 18.440 .000 \\
\hline
\end{tabular}

Sumber: https://finance.detik.com/berita-ekonomi-bisnis/d-5735421/daftar-10-jagoan-e-commerce-di-

indonesia/amp\#aoh=16375867377053\&referrer=https\%3A\%2F\%2Fwww.google.com\&amp_tf=Dari\%20\%251\%24s\&ampshare=https\%3A \%2F\%2Ffinance.detik.com\%2Fberita-ekonomi-bisnis\%2Fd-5735421\%2Fdaftar-10-jagoan-e-commerce-di-indonesia

Berdasarkan data di atas, dilihat dari jumlah penggunanya aplikasi blibli berada diurutan ke-5 dengan jumlah yang telah didownload oleh pengguna sebanyak lebih dari 10.000.000, sedangkan aplikasi tokopedia, shopee dan lazada telah didownload lebih dari 100.000.000 pengguna dan bukalapak yang telah didownload lebih dari 50.000.000 pengguna. Dan jika dilihat dari kunjungan webnya, aplikasi blibli juga memiliki jumlah yang paling sedikit dibandingkan aplikasi lainnya yaitu hanya sebanyak 1.440.000. Maka, dapat disimpulkan berdasarkan visi yang pertama aplkasi blibli ini belum mampu untuk mencapai tujuan yang telah ditargetkan atau dengan kata lain apliksi bibli belum cukup efektif sebagai salah satu e-commece dengan jumlah pelanggan terbanyak. Selanjutnya ditinjau dari visi yang kedua yaitu blibli berkomitmen untuk memberikan kenyamanan dan kepuasan belanja melalui 24/7 layanan customer care serta kepastian 15 hari pengembalian. Dan berikut adalah data yang telah kami peroleh mengenai visi aplikasi blibli yang kedua. 
Tabel 2. Data Persentase Kenyamanan dan Kepuasan Belanja, Pelayanan CS Aplkasi Blibli serta Kepastian 15 Hari Pengembalian

\begin{tabular}{|l|c|c|c|}
\hline \multicolumn{2}{|c|}{ Keterangan } & \multicolumn{3}{c|}{ Persentase } \\
\cline { 2 - 4 } & Baik & Kurang & Tidak \\
\hline Kenyamanan dan kepuasan belanja & $40 \%$ & $30 \%$ & $30 \%$ \\
\hline Kenyamanan dan kepuasan layanan CS & $40 \%$ & $30 \%$ & $30 \%$ \\
\hline Kepastian 15 hari pengebalian & $35 \%$ & - & $65 \%$ \\
\hline
\end{tabular}

Sumber: Data primer (diolah)

Berdasarkan penelitian yang kami lakukan terhadap 20 penguna aplikasi blibi, hasil yang kami dapatkan adalah sebesar $40 \%$ pengguna menyatakan bahwa aplikasi blibi telah memberikan kenyamanan dan kepuasan belanja melalui $24 / 7$ layanan customer care serta kepastian 15 hari pengembalian, sebesar $30 \%$ menyatakan bahwa aplikasi blibli kurang dalam memberikan kenyamanan dan kepuasan belanja melalui 24/7 layanan customer care dan sebesar 30\% menyatakan bahwa aplikasi blibli tidak memberikan kenyamanan dan kepuasan belanja melalui 24/7 layanan customer care. Tanggaan pengguna mengenai kenyamanan dan kepuasan belanja melalui 24/7 layanan customer care sangat beragam, mulai dari yang positif dan negative. Ada yan menyatakan kalua produk yang dijual di aplikasi ini original namun sisi negatifnya proses pengiriman barang tersebut sangat lama dan merepotkan jika akan melakukan pembatalan pembelian, ada juga yang menyatakan bahwa customer service aplikasi blibli ini sangat sulit dihubungi dan jarang merespon keluhan-keluhan pengguna, namun Sebagian pengguna juga menyatakan bahwa customer service aplikasi blibli sangat ramah dan juga membantu. Mengenai kepastiian 15 hari pengembalian aplikasi blibli ini mendapat persentase sebesar $35 \%$ bensr dan sebesar $65 \%$ tidak benar, karena Sebagian pengguna menyatakan bahwa mereka justru tidak mendapatan respon saat akan melakukan retur atau pengembalian barang dan sebagain lainnya menyatakan bahwa mereka bisa melakukan retur atau pengembalian barang. Maka, dapat disimpulkan berdasarkan visi yang kedua aplikasi blibli ini cukup efektif dalam memberikan kenyamanan dan kepuasan belanja melalui 24/7 layanan customer care, namun dinilai tidak efektif dalam kepastian 15 hari penembalian barang.

Visi yang terakhir yaitu pilihan pembayaran yang lengkap, menurut kami sendiri aplikasi blibli sudah menyedikan metode yang lengkap dimana dikutip dari web blibli aplikasi ini menyediakan metode pembayaran melalui alfa group,bayar pesanan di blibli, biaya pelayanan, bukti pembelian, cicilan $0 \%$, cicilan tanpa kartu kredit, COD, debit instan, layanan indomaret, internet bangking, kartu kredit, pos Indonesia, transfer melalui virtual akun dan uang elektronik. Maka dari itu berdasarkan visi yang ketiga aplikasi blibli ini dapat dikatakan efektif menjadi salah satu e-commerce.

\section{KESIMPULAN}

Berdasarkan hasil penelitian yang telah kami lakukan maka dapat disimpulkan bahwa aplikasi blibli termasuk ke dalam salah satu e-commerce yang menyediakan berbagai informasi yang bisa kita dapatkan. Informasi tersebut diantaranya adalah menyediakan berbagai fitur yang dapat digunakan dan dimanfaatkan seperti fitur tagihan dan isi ulang, fitur travel,fitur belanja dan fitur keuangan. Dalam fitur-fitur tersebut kita bisa mendapatkan informasi lebih lanjut atau lebih detail mengenai suatu produk yang ditawarkan oleh penjual seperti fitur deskripsi yang mencakup merek produk, kategori produk, deskripsi produk, harga produk, size produk, spesifikasi produk dan lain sebagainya. Selain itu, aplikasi blibli juga menyediakan layanan chat untuk memudahkan komunikasi antara konsumen dan penjual agar konsumen bisa menanyakan lebih lanjut mengenai produk yang diminatinya kepada penjual yang bersangkutan. Terakhir aplikasi blibli juga menyediakan fitur ulasan yang berisi penilaian pembeli mengenai suatu produk yang telah dibelinya, ulasan ini sangat bermanfaat untuk calon pembeli selanjutnya dalam menentukan pilihannya untuk membeli atau tidak produk yang diminatinya. Dan sebagai salah satu e-commerce yang cukup populer blibli juga patut ditelusuri mengenai keefektifannya sebagai matketplace jika dilihat berdasarkan data hasil penelitian yang kami lakukan, merujuk pada visi dari aplikasi blibli sendiri aplikasi blibli dinyatakan kurang efektif dalam visi yang pertama mengenai jumlah pengguna aplikasi ecommerce terbanyak, karena aplikasi blibli ini berada di urutan ke lima jika dibandingkan dengan aplikasi ecommerce seperti tokopedia, shopee,lazada dan bukalapak yang artinya berada diurutan terakhir dengan jumlah pengguna yang paling sedikit. Selanjutnya,jika merujuk pada kenyamanan dan kepuasan belanja serta layanan CS aplikasi blibli dinilai cukup efektif dengan jumalah persentase efektif sebesar $40 \%$, jumlah persentase kurang 
efektif sebesar 30\% dan jumlah persentase tidak efektif sebesar 30\%. Namun jika merujuk pada kepastian 15 hari pengembalian aplikasi blibli dinilai tidak efektif karena sebanyak $65 \%$ pengguna menyatakan tidak bisa melakukan retur atau pengembalian barang dan sebanyak $35 \%$ pengguna menyatakan bahwa mereka bisa melakukan retur atau pengembalian barang. Dan yang terakhir, aplikasi blibli dinilai efektif jika merujuk pada metode pembayaran yang disediakan karena aplikasi blibli ini menyediakan metode pembayaran yang cukup lengkap, diantaranya adalah alfa group, bayar pesanan di blibli, biaya pelayanan, bukti pembelian, cicilan $0 \%$, cicilan tanpa kartu kredit, COD, debit instan, layanan indomaret, internet bangking, kartu kredit, pos Indonesia, transfer melalui virtual akun dan uang elektronik.

\section{REFERENSI}

[1]. Abdirrosyid , A., \& Misbahuddin, I. M. (2017, September 03). Analisis Perancangan Sistem Informasi. Retrieved November 15, 2021, from ilhammisbahuddin.blogspot.com: http://ihammisbahuddin.blogspot.com/2017/09/executive-information-system-executive.html?m=1

[2]. Adani, M. R. (2020, Agustus 25). Sistem Informasi Manajemen dan Manfaat untuk Bisnis. Retrieved November 3, 2021, from sekawanmedia.co.id: https://www.sekawanmedia.co.id/sistem-informasimanajemen/\#: :text=Sistem\%20informasi\%20manajemen\%20\%28SIM\%29\%20adalah\%20sekelompok \%20atau\%20sekumpulan,sangat\%20berguna\%20untuk\%20menunjang\%20dan $\% 20$ mengendalikan $\% 20$ operasi\%20perusahaan.

[3]. Adani, M. R. (2021, Maret 17). Pengertian Sistem Informasi dan Contoh Penerapan pada Dunia Industri. Retrieved November 11, 2021, from sekawanmedia.co.id: https://www.sekawanmedia.co.id/sisteminformasi/

[4]. Aryatama, A. (n.d.). ANALISIS E-COMMERCE BLIBLI. 5.

[5]. Fitrah, M., \& Luthfiyah. (2017). Metodologi Penelian Penelitian Kualitatif, Tindakan Kelas \& Studi Kasus. Jawa Barat: CV Jejak.

[6]. Kusniadi, A. (n.d.). PENERAPAN KONSEP E-BISNIS PADA PERUSAHAAN BLIBLI.COM. 2.

[7]. Lathiif, I. M. (2019, Juni 1). Pengaruh Kepercayaan, Kemudahan, dan Kualitas Informasi Terhadap Keputusan Pembelian. 3.

[8]. Lathiif, I. M. (2019). Pengaruh Kepercayaan, Kemudahan, Dan Kualitas Informasi terhadap Keputusan Pembelian. 9.

[9]. Noer, D., \& Dayana, I. (2021). Buku Sains Dasar. Guepedia.

[10]. Nugraha, J. (2021, Januari 21). Sistem Informasi Manajemen dan Manfaat untuk Bisnis. Retrieved November 08, 2021, from Merdeka.com: https://www.sekawanmedia.co.id/sistem-informasi-manajemen/

[11]. Prawiro, M. (2018, November 07). Pengertian Efektivitas: Kriteria, Aspek, dan Contoh Efektivitas. Retrieved from Maxmanroe: https://www.maxmanroe.com/vid/manajemen/pengertian-efektivitas.html

[12]. Rahma, A. (2021, Juni 18). Penjelasan Lengkap Mengenai Sistem Informasi Manajemen. Retrieved November 11, 2021, from majoo.id: https://majoo.id/solusi/detail/sistem-informasi-manajemen 
[13]. Saat, S., \& Mania, S. (2020). Pengantar Metodologi Penelitian: Panduan bagi Peneliti Pemula. Sulawesi Selatan : PUSAKA ALMAIDA.

[14]. Sendari, A. A. (2021, Februari 14). Pengertian Sistem Menurut Para Ahli, Karakteristik dan Macamnya. Retrieved November 08, 2021, from Liputan6.com: https://m.liputan6.com/hot/read/4482562/pengertiansistem-menurut-para-ahli-karakteristik-dan-macamnya

[15]. Sugiyono. (2010). Metode Penelitian Kuantitatif dan R\&D. Bandung: Alfabeta. 